\title{
EVALUATION OF THE SOCKET SHIELD TECHNIQUE FOR IMMEDIATE IMPLANTATION
}

\author{
Dalia A. Barakat $B D S^{l}$, Ragab S. Hassan $P h D^{2}$, Riham M. Eldibany $P h D^{2}$
}

\begin{abstract}
INTRODUCTION: Numerous publications have verified that tooth extraction is followed by dimensional changes of the alveolar ridge contour. The resorption of the alveolar ridge is more pronounced on the buccal than on the lingual aspect of the extraction socket. In particular, in the aesthetic zone, the successive soft and hard tissue deficiencies can interfere with optimal implant positioning and hamper the overall aesthetic outcome of implant-supported prostheses.

OBJECTIVES: This study was designed to evaluate the socket shield technique clinically and radiographically as a new modality for immediate implantation in comparison to the conventional technique.

MATERIALS AND METHODS: twenty patients were included in this study $(n=20)$. They were divided in two groups; group I: Ten maxillary single rooted teeth were extracted followed by immediate implant placement using the socket shield technique. Group II: Ten maxillary single rooted teeth were extracted followed by immediate implant placement using the conventional technique. All implants were evaluated clinically and radiographically to evaluate bone loss on intervals of 1,4 and 7 months.

RESULTS: the mean horizontal and vertical bone loss value in socket shield technique group was $0.09 \pm 0.03 \mathrm{~mm} \& 0.43 \pm 0.23 \mathrm{~mm}$ contrary to the conventional implantation after 7 months follow up, which was $0.33 \pm 0.14 \mathrm{~mm} \& 1.56 \pm 0.77 \mathrm{~mm}$ which was statistically significant.

CONCLUSIONS: The socket shield technique was beneficial in preserving the buccal bone plate

KEYWORDS: ridge preservation, immediate implant, socket shield

1- Bachelor of Dentistry, BDS, Faculty of Dentistry, Alexandria University, Alexandria, Egypt.

2- Professor of Oral and Maxillofacial Surgery, BDS, MSc, PhD, Faculty of Dentistry, Alexandria University, Alexandria, Egypt.
\end{abstract}

\section{INTRODUCTION}

Replacing missing teeth to restore function and aesthetics is one of the main goals of dentistry (1). For the past years, osseointegrated dental implants have been accepted as one of the major treatment concepts for restoring completely and partially edentulous patients (2).

In order to overcome the negative consequences of tooth extraction, different techniques such as immediate implant placement (3) and ridge preservation procedure (4), graft materials $(5-8)$ and/or barrier membrane $(9,10)$ have been proposed to maintain the ridge dimension to a certain amount. However, these methods could not completely preserve the coronal part of facial bone walls (11).

The marked alterations after tooth extraction appear to be attributable to the loss of periodontal ligament and the consecutive trauma in particular at the buccal bone plate (12). Thus, it can be assumed that root retention may have an influence on the occurring resorption process (13).

Clinical studies have tested the hypothesis that root retention, either of vital or pulpless teeth, may avoid tissue alterations after tooth extraction (13).

In 2001 Filippi et al (14), showed in a case report that decoronation of an ankylosed tooth preserved the alveolar bone before implant placement. Few studies have demonstrated that the preservation of decoronated roots in the alveolar process not only helps maintaining existing bone volume but also enables vertical bone growth, which can be observed coronally to the decoronated root (15-17).

Also, Salama et al. in 2007 (18) reported that the root submergence technique (RST) maintains the natural attachment apparatus of the tooth in the pontic site, which in turn allows for complete preservation of the alveolar bone frame and assists in the creation of an aesthetic result in adjacent multiple-tooth-replacement cases.

In 2010, Hürzeler et al (13) introduced a new approach (the socket shield technique) for immediate implantation in the extraction socket of teeth with healthy periodontal tissues. By only partial root removal (leaving a buccal root fragment in site) improved results can be achieved regarding the preservation of the buccal alveolar bone.

Therefore, the present clinical study was conducted to evaluate the socket-shield technique in the esthetic zone.

\section{MATERIALS AND METHODS}

This Randomized Controlled Clinical Trial study was conducted on twenty adult patients of both genders. All patients had maxillary single rooted teeth indicated for extraction and immediate implant placement. Appropriate ethical clearance was granted from the institution in which the study was carried out, also an informed consent was obtained from all patients. The patients were selected from the Out Patient Clinic of the Oral \& Maxillofacial Surgery Department, Faculty of Dentistry, Alexandria University. Patients were divided into two groups:

The study group: Ten maxillary single rooted teeth were extracted followed by immediate implant placement using the socket shield technique.

The control group: Ten maxillary single rooted teeth were extracted followed by immediate implant placement using the conventional technique.

The inclusion criteria of this study were; patients' age ranging from $20-50$ years, adequate oral hygiene, and labial bone plate less than $1.5 \mathrm{~mm}$ in thickness or cases with labial root curvatures.

While the exclusion criteria were; periapical or periodontal active infection involving the teeth to be extracted, patients receiving chemotherapy or radiotherapy, alcohol or drug abuse, heavy smokers, patients who have uncontrolled systemic disorders such as uncontrolled diabetes mellitus, autoimmune disease and patients with parafunctional habits such as bruxism, clenching, excessive gum chewing, lip or fingernail biting. 


\section{The Implant system}

Dentium superline system implants (Emergo Europe,Seoul, Korea) with different diameters $(3.6,4.0,4.5,5.0$, and $5.8 \mathrm{~mm})$ and lengths $(7,8,10,12$ and $14 \mathrm{~mm})$. It is known for its tapered body design and Sandblasting with Large grit and Acid etching (SLA) surface treatment that facilitates the osseointegration process. The double-threaded design of SuperLine dental implants reduces implant insertion time. All implant sizes share the same internal hex.

\section{A -Preoperative phase}

All patients underwent pre-operative clinical examination: Patients' data were collected; name, gender and age, medical and dental histories were taken and the oral mucosa of the edentulous area was examined by inspection and palpation. Also, all patients underwent standardized periapical radiography to detect any periapical pathology and a pre-operative panoramic radiograph examination to pre-operative panoramic radiograph examination to select the proper size of the implants to be installed.

\section{B -Operative phase}

All patients were instructed to rinse with chlorhexidine mouth wash (Listermix plus, SIGMA Pharmaceutical Industries, Egypt) immediately before operation for 2 minutes.

All patients were treated using local anesthesia, articaine HCL and epinephrine 1:20.000 (Septodont, by Novocol Pharmaceutical of Canada, Inc.)

In the study group, the tooth was decoronated with a coarsed grained diamond rose head bur, $2.3 \mathrm{~mm}$ in diameter using high speed headpiece under copious irrigation. The root was then hemisected using Lindemann cutter C162 (Jota, Switzerland) of $11 \mathrm{~mm}$ in length and 016 in diameter with the full length of the bur in a mesio-distal direction from the gingival margin till the apex of the root to separate the palatal and the labial part of the root. Then atraumatic removal of the palatal fragment of the root was done using periotome and forceps. The buccal fragment was then reduced using surgical bur leaving a thin layer of the root aspect attached to the labial plate of the bone and the socket was debrided gently and irrigated with physiologic saline solution. The initial marking or preparation of the implant bed was done with a pilot drill of $2.2 \mathrm{~mm}$, the osteotomy was then widened using an intermediate drill and the final drill according to the diameter of the implant. The implant was then inserted into the bone palatal to the root. (Figs 1, 2)

In the control group, atraumatic extraction using periotome and forceps was performed to preserve the available alveolar bone and the socket was debrided gently after tooth extraction using curettes, and irrigation by physiologic saline solution. The initial marking and preparation of the implant bed was done with a pilot drill of $2.2 \mathrm{~mm}$, the osteotomy was then widened using an intermediate drill and the final drill according to the diameter of the implant, the implant was then inserted into the bone using a Ratchet. (Figs 3)

In all patients the SmartPeg ${ }^{\mathrm{TM}}$ was then attached to the implant fixture to measure the implant stability using Osstell ISQ (Osstell AB, Göteborg, Sweden). The healing cap was then placed. Then Adaptive sutures were done mesial and distal to the implant with $3 / 0$ black silk. (Figs 2 , 4)

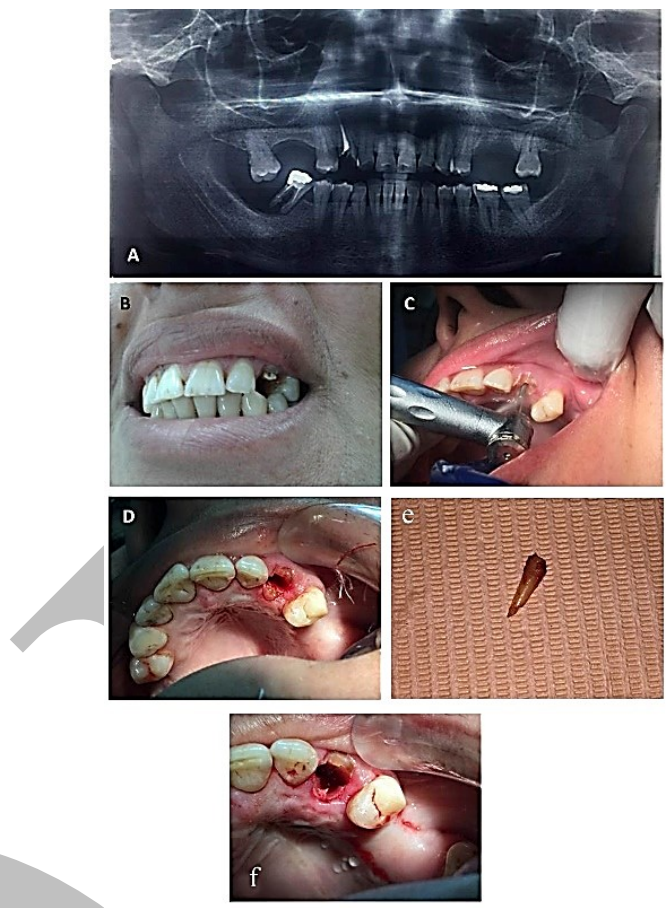

Figure (1): a photograph showing the socket shield technique procedure. (a) Preoperative panoramic radiograph showing maxillary left canine remaining root. (b) Preoperative clinical view. (c) hemisection of the root. (d) Root sectioning. (e) Palatal fragment. (f) Labial fragment intact.

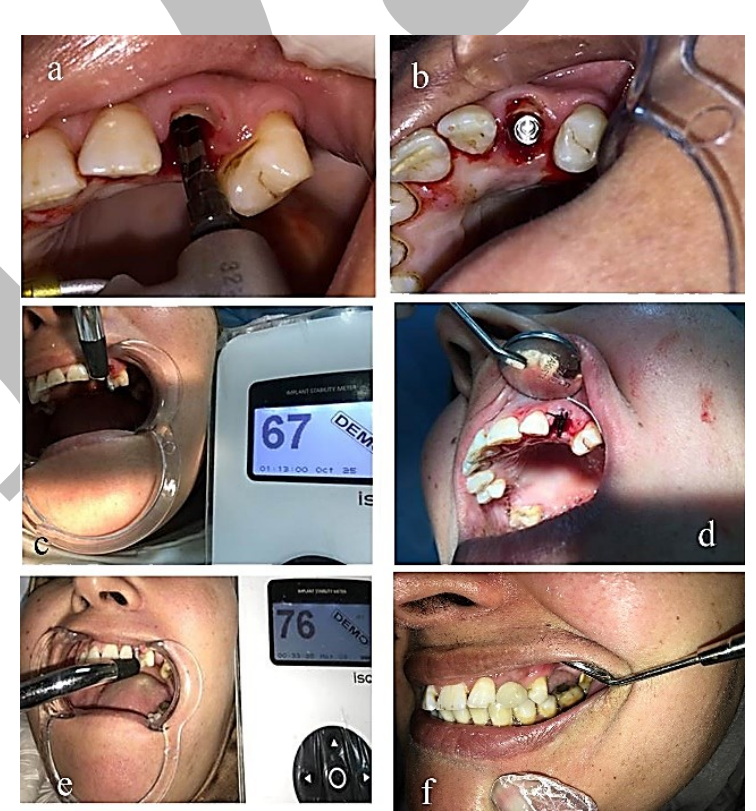

Figure (2): A photograph showing the implant placement surgical procedures and implant stability measurement in the socket shield technique. (a) Intermediate drill. (b) The root fragment in contact with the implant. (c) Primary stability measurement displayed on the portable instrument screen. (d) Suturing of the socket. (e) Secondary stability measurement after four months from implant placement displayed on the portable instrument screen. (f) Final prosthesis.

\section{C-Postoperative phase}

All patients were advised to apply cold packs extra orally intermittently every 10 minutes for 2 hours on the first day. Chlorohexidine mouth wash was started on the 2 nd postoperative day for one week and the sutures were removed after one week post surgically. Amoxicillin $875 \mathrm{mg}$ /claviulanic acid $125 \mathrm{mg}$ antibiotic tablet (Augmentin $1 \mathrm{gm}$, 
Glaxosmithkline, Australia), one tablet every 12 hours for 5 days postoperatively. Diclofenac sodium non-steroidal anti-inflammatory drugs $50 \mathrm{mg}$ tabs (Cataflam, Novartis pharma, Basel, Switzerland) one tablet every 8 hours for five days.
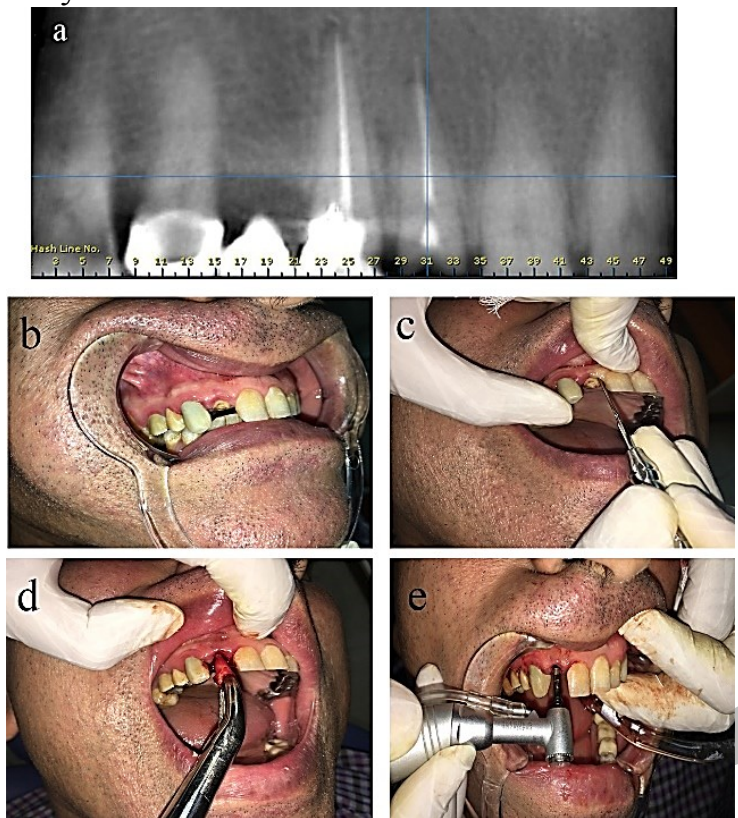

Figure (3): A photograph showing the implant placement surgical procedures in the control group. (a) Preoperative panoramic radiograph showing maxillary right lateral remaining root. (b) Preoperative clinical view. (c) atraumatic extraction using periotome. (d) atraumatic extraction using forceps. (e) Intermediate drill.

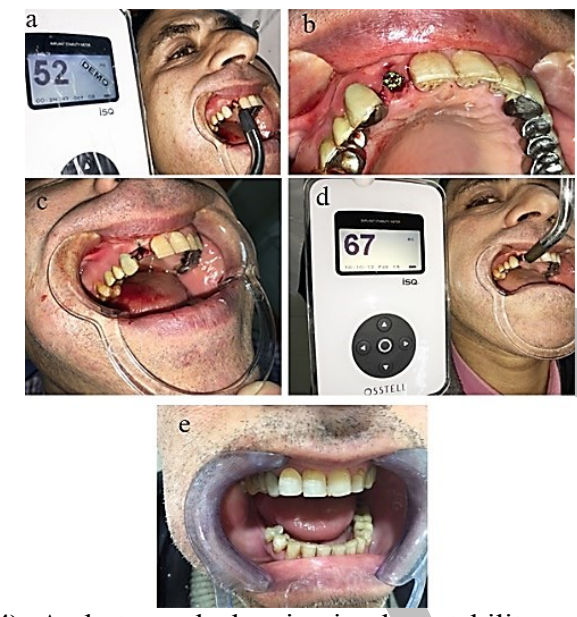

Figure (4): A photograph showing implant stability measurement in the control group. (a) Primary stability measurement displayed on the portable instrument screen. (b) Implant in place with cover screw. (c) Suturing of the socket. (d) Secondary stability measurement after four months from implant placement displayed on the portable instrument screen. (e) Final prosthesis.

\section{D- Follow up phase \\ Clinical evaluation}

Early follow up: was performed daily for the first week after implant placement, then weekly for the first month for any signs of infection, pain, swelling or any postoperative complications.

Patients were evaluated clinically for:

Pain was evaluated using the Visual Analogue Scale. A score of 0 was defined as no pain, and 10 points was defined as the most sever intolerable pain.
Post-operative complications were evaluated as the presence of pain, tenderness, infection or swelling that may indicate the presence of peri-implant disease and possible accelerated bone loss. Any post-operative complications were recorded.

Long term follows up was performed at 4 and 7 months after surgery regarding ginigival and periodontal condition and implant stability.

Patients were evaluated clinically for:

Peri-implant probing depth (19) measuring the distance from the gingival margin buccal, palatal, mesial and distal crestal bone margins. Mesial and distal pockets were measured from the buccal aspect as close as possible to contact points while facial and lingual pockets were measured at the midline of the implant.

Sulcus bleeding index (20) as early signs of gingivitis indicated as Bleeding on probing.

Measurement of implant secondary stability was performed by Osstell TM. after 4 months from implant placement. (Figs 2, 4)

\section{Radiographic evaluation}

All implants involved in this study were followed up radiographically by Cone beam computed tomography (CBCT) to evaluate horizontal and vertical dimensional changes to the labial bone following maxillary anterior single immediate implant placement. It was done immediately after implant placement and after 4 and 7 months.

Sagittal images were used to measure buccal bone-width as follows:

Horizontal bone level: Starting from the implant shoulder a fixed distance was taken as a reference line and the horizontal bone level was measured throughout the three follow up periods. (Figs 5)

Vertical bone level: A line from the apex of the implant parallel to the reference horizontal line of the CBCT was drawn and the marginal bone level was measured from the reference line to the marginal bone crest parallel to the implant. (Figs 5)

\section{E- Prosthetic phase}

Final prosthetic treatment (porcelain fused to metal crown) was performed after four months. (Figs 2,4)
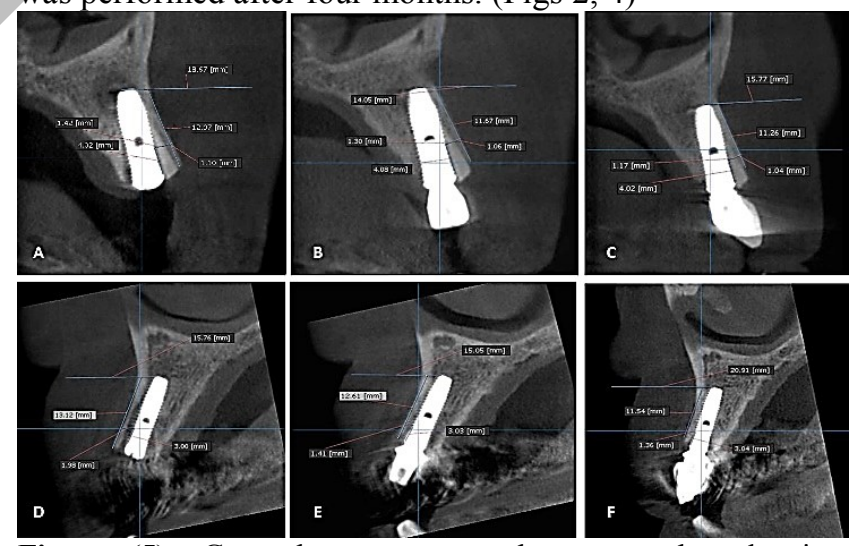

Figure (5): Cone beam computed tomography showing horizontal $(\mathrm{H})$ and vertical $(\mathrm{V})$ bone level in study and control group throughout the follow up period. (a) H\&V bone level in study group at time of implant placement. (b) $\mathrm{H} \& \mathrm{~V}$ bone level in study group after four months, (c) H\&V bone level in study group after seven months. (d) H\&V bone level in control group at time of implant placement. (e) $\mathrm{H} \& \mathrm{~V}$ bone level in control group after four months. (f) $\mathrm{H} \& \mathrm{~V}$ bone level in control group after seven months 


\section{STATISTICAL ANALYSIS}

Data were represented as mean and standard deviation. Repeated measures analysis of variance (ANOVA) test was used to compare numeric variables within the studied group of patients. Post Hoc test was done if ANOVA or Friedman tests were positive. Using SPSS version in all tests, result was considered statistically significant if the $p$ - value was less than 0.05 .

\section{RESULTS}

Twenty implants were placed in a total of twenty patients requiring extraction of maxillary single rooted teeth. Their ages ranged between 20 and 50 years with mean age of 35 years of both sexes ( 8 males and 12 females). Implants used in the study group had diameters of $3.3,3.8 \mathrm{~mm}$ and length $12,14 \mathrm{~mm}$ while in the control group the diameters were $3.3,3.8,4.3 \mathrm{~mm}$ and length $10,12,14 \mathrm{~mm}$. Teeth extracted in the study group were 6 maxillary incisors and 4 maxillary canines while in the control group teeth extracted were 7 maxillary incisors and 3maxillary canines.

All patients underwent surgery in local anesthesia and no complications had been recorded during the operation.

\section{Clinical evaluation}

All patients had been examined periodically during the follow-up period up to 7 months. Healing was uneventful in all cases with no post-operative complications.

1. Pain, swelling or infection; all patients experienced slight to mild pain at the surgical site which disappeared completely after the 2 nd and 3 rd days \& all patients experienced mild to moderate edema which also disappeared completely after five days. All patients continued the follow up period without any signs of infection,

2. Mean probing depth; Mean probing depth decreased in all patients of the study and control group after seven months. The decrease in all patients was statistically significant (Table 1)

3. Sulcus bleeding index; All the patients had score $(0)$ of sulcus bleeding index all over the follow up period.

4. Implant stability evaluation; in the study group, the mean implant stability quotient immediate post-surgical was $60.30 \pm 6.43$ ISQ. There was an increase after 7th months to $69.80 \pm 3.77$ ISQ which was statistically significant. In the control group the mean implant stability quotient immediately post-operative was 57.20 \pm 9.15 ISQ there was an increase after 7 months to 65.60 \pm 5.66 ISQ which was statistically significant. The differnce between the two groups was statistically insignificant. $(\mathrm{P}=0.392$ in primary stability $)(\mathrm{p}=0.066$ after four months) (Figs 6) (Table 2)

\section{Radiographic evaluation}

All patients had been examined radiographically using Cone beam computed tomography (CBCT) it was done to evaluate horizontal and vertical dimensional changes to the labial bone following maxillary anterior single immediate implant placement. (Figs 5)

1. Horizontal bone loss; in the study group the mean horizontal bone loss after 7 months was $0.10 \pm 0.03 \mathrm{~mm}$, while in control group the mean horizontal bone loss after 7 months was $0.34 \pm 0.11 \mathrm{~mm}$. The difference in horizontal bone loss between both groups after seven months from implant placement was statistically significant. (Figs 6) (Table 3)
2. Vertical bone loss; in the study group the mean vertical bone loss after 7 months was $0.44 \pm 0.24 \mathrm{~mm}$, while in control group the mean vertical bone loss after 7 months was $1.61 \pm 0.78 \mathrm{~mm}$. The difference in vertical bone loss between both groups after seven months from implant placement was statistically significant. (Figs 6) (Table 3)

Table 1: Comparison between the two studied groups according to mean probing depth.

\begin{tabular}{|c|c|c|c|c|}
\hline Mean probing depth & Study $(n=10)$ & Control $(n=10)$ & $\begin{array}{l}\text { Test of } \\
\text { sig. }\end{array}$ & $\mathbf{p}$ \\
\hline $\begin{array}{l}\text { After } 4 \text { months } \\
\text { Min. - Max }\end{array}$ & $1.75-2.50$ & $1.60-3.80$ & \multirow{3}{*}{$\begin{array}{c}\mathrm{t}= \\
2.870^{*}\end{array}$} & \multirow{3}{*}{$0.010^{*}$} \\
\hline Mean \pm SD & $2.05 \pm 0.31$ & $2.75 \pm 0.70$ & & \\
\hline Median & 2.0 & 2.78 & & \\
\hline $\begin{array}{l}\text { After } 7 \text { months } \\
\text { Min. - Max }\end{array}$ & $1.50-2.25$ & $1.0-3.20$ & \multirow{3}{*}{$\mathrm{t}=1.800$} & \multirow{3}{*}{0.089} \\
\hline Mean \pm SD & $1.73 \pm 0.28$ & $2.12 \pm 0.64$ & & \\
\hline Median & 1.63 & 2.13 & & \\
\hline $\begin{array}{l}\text { Change from } 4 \\
\text { months to } 7 \text { months } \\
\text { Min. - Max }\end{array}$ & $0.25-0.50$ & $0.25-1.10$ & \multirow{3}{*}{$\mathrm{U}=21.0^{*}$} & \multirow{3}{*}{$0.019^{*}$} \\
\hline Mean \pm SD & $0.33 \pm 0.12$ & $0.63 \pm 0.32$ & & \\
\hline Median & 0.25 & 0.60 & & \\
\hline $\begin{array}{l}\text { \% of Change from } 4 \\
\text { months to } 7 \text { months } \\
\text { Min. - Max } \\
\end{array}$ & $10.0-25.0$ & $9.09-39.29$ & \multirow[t]{3}{*}{$\mathrm{U}=32.0$} & \multirow[t]{3}{*}{0.171} \\
\hline Mean \pm SD & $15.80 \pm 4.94$ & $23.14 \pm 11.31$ & & \\
\hline Median & \begin{tabular}{|l|}
14.29 \\
\end{tabular} & 25.0 & & \\
\hline
\end{tabular}

$t, p$ : $t$ and $p$ values for Student t-test for comparing between the two groups U, p: U and p values for Mann Whitney test for comparing between the two groups

*: Statistically significant at $\mathrm{p} \leq 0.05$

\section{DISCUSSION}

The success of osseointegrated dental implants depends on whether there is sufficient volume of healthy bone at the recipient site at the time of implant placement. The placement of an implant at a site with a thin buccal crestal ridge (e.g. postextraction ridge) mostly is followed by a significant buccal resorption. Thus, it seems prudent to prevent alveolar ridge resorption and make efforts to preserve the buccal alveolar bone during extraction procedures (21).

In this study, the peri-implant probing depth of the study group improved significantly over the healing period. This reduction of peri-implant probing depth indicates improvement of the collagen fibers arrangement and density around dental implants preventing loss of osseointegration and periimplantitis and the shield of root did not interfere with it (22).

The primary implant stability in the study group was $60.30 \pm 6.43$ ISQ, which increased to be $69.80 \pm 3.77$ ISQ after seven months from implant placement. This agreed with Degidi's et al study in 2010 (23) all the implants with an initial stability (ISQ) bellow 46 ISQ failed, while in those with ISQ over 60, osteointegration was successful.

Regarding the mean of horizontal and vertical bone loss with the socket shield technique, these results agreed with Bäumer et al in 2015 (24) where they reported a mean of 1 $\mathrm{mm}$ horizontal loss after final restoration.

Also, Chen and Pan in 2013 (9) supported this study and reported $0.72 \mathrm{~mm}$ of buccal bone resorption. In addition, Bäumer et al in 2017(25) where they reported the marginal bone loss Changes at the mesial and distal aspects were 0.33 and $0.17 \mathrm{~mm}$. Furthermore, Abadzhiev et al in 2014 (26), where they reported $0.8 \mathrm{~mm}$ bone loss. 
Table 2: Comparison between the two studied groups according to implant stability quotient (ISQ).

\begin{tabular}{|c|c|c|c|c|}
\hline Osstell & Study $(n=10)$ & Control $(n=10)$ & $\begin{array}{c}\text { Test of } \\
\text { sig. }\end{array}$ & $\mathbf{p}$ \\
\hline $\begin{array}{l}\text { Time of implant } \\
\text { placement } \\
\text { Min. - Max }\end{array}$ & $49.0-68.0$ & $43.0-70.0$ & \multirow{3}{*}{$\begin{array}{c}\mathrm{t}= \\
0.877\end{array}$} & \multirow[t]{3}{*}{0.392} \\
\hline Mean \pm SD & $60.30 \pm 6.43$ & $57.20 \pm 9.15$ & & \\
\hline Median & 59.0 & 57.0 & & \\
\hline \multicolumn{5}{|l|}{ After 4 months } \\
\hline Min. - Max & $63.0-76.0$ & $55.0-72.0$ & \multirow{3}{*}{$\begin{array}{c}\mathrm{t}= \\
1.954\end{array}$} & \multirow{3}{*}{0.066} \\
\hline Mean \pm SD & $69.80 \pm 3.77$ & $65.60 \pm 5.66$ & & \\
\hline Median & 69.50 & 67.50 & & \\
\hline $\begin{array}{l}\text { Change from time } \\
\text { of implant } \\
\text { placement to } 4 \\
\text { months } \\
\text { Min. - Max }\end{array}$ & $1.0-16.0$ & $1.0-19.0$ & \multirow[t]{3}{*}{$\begin{array}{c}\mathrm{U}= \\
43.0\end{array}$} & \multirow[t]{3}{*}{0.595} \\
\hline Mean \pm SD & $9.50 \pm 5.32$ & $8.40 \pm 6.02$ & & \\
\hline Median & 10.0 & 8.0 & & \\
\hline $\begin{array}{l}\text { \% of Change from } \\
\text { time of implant } \\
\text { placement to } 4 \\
\text { months } \\
\text { Min. - Max }\end{array}$ & $1.49-28.57$ & $1.43-38.78$ & \multirow[t]{3}{*}{$\begin{array}{c}\mathrm{U}= \\
48.0\end{array}$} & \multirow[t]{3}{*}{0.880} \\
\hline Mean \pm SD & $16.61 \pm 10.13$ & $16.25 \pm 12.81$ & & \\
\hline Median & 17.38 & 14.72 & & \\
\hline
\end{tabular}

$t, p: t$ and $p$ values for Student $t$-test for comparing between the two groups $\mathrm{U}, \mathrm{p}$ : $\mathrm{U}$ and $\mathrm{p}$ values for Mann Whitney test for comparing between the two groups

In this study retaining a root-shell adjacent to the buccal crestal bone and placing an implant engaged to the palatal socket wall immediately were able to maintain the contour of the ridge. As the physiological processes which take place immediately after tooth extraction up to the end of the 1st week included increasing of the number of the osteoclasts on the outside as well as on the inside of the buccal and lingual bone walls. The presence of osteoclasts on the inner surface of the socket walls indicated that the bundle bone, which is closely related to the periodontal tissue, is being resorbed. Anatomically, the buccal bone plate of the teeth is thinner than lingual or palatal

Therefore, as the bundle bone is a tooth-dependent tissue, it will gradually disappear after extraction, thus, since there was more bundle bone in the crest of the buccal than the lingual wall, hard tissue loss became most pronounced in the buccal wall (27). These scientific evidences and the empirical experience of immediate implant placement in fresh extraction sockets have led the thought that probably by preserving the periodontal tissues on the buccal part of the socket we could prevent bone resorption in this critical area, as no osteoclastic remodeling of the coronal part of the buccal plate. (28)

This technique of retaining roots to avoid alveolar bone remodelling was agreed with multiple experimental and clinical studies that have shown that the decoronation of ankylosed teeth predictably preserves the alveolar ridge contour (29-32). Salama et al.in 2007 (18) described the Root Submergence Technique (RST) which resulted in maximum preservation of the surrounding alveolar bone and soft tissues.

In the study performed by Baumer et al in 2017 (25) one of the cases had apical resorption of the shield, which might be due to microbiological leftovers in the root apex, which is indicative of the technique sensitivity of this approach. But in this study teeth shells in all patients were intact through the follow up period and no apical resorption took place.

This study, demonstrated good prognosis of socket shield technique combined with immediate implant placement for replacing a failing tooth and it maintained the ridge shape.

Table 3: Comparison between the two studied groups according to horizontal and vertical bone loss.

\begin{tabular}{|c|c|c|c|c|}
\hline Horizontal bone loss & Study $(n=10)$ & $\begin{array}{c}\text { Control }(n= \\
10)\end{array}$ & $\mathbf{U}$ & $\mathbf{P}$ \\
\hline $\begin{array}{l}\text { Change from time of } \\
\text { implant placement to } \\
4 \text { months } \\
\text { Min. - Max }\end{array}$ & $0.02-0.08$ & $0.10-0.57$ & \multirow[t]{3}{*}{0.0} & \multirow[t]{3}{*}{$<0.001$} \\
\hline Mean \pm SD & $0.05 \pm 0.02$ & $0.22 \pm 0.14$ & & \\
\hline Median & 0.05 & 0.18 & & \\
\hline $\begin{array}{l}\text { Change from time of } \\
\text { implant placement to } \\
7 \text { months } \\
\text { Min. - Max } \\
\end{array}$ & $0.04-0.13$ & $0.20-0.62$ & \multirow[t]{3}{*}{0.0} & \multirow[t]{3}{*}{$<0.001^{*}$} \\
\hline Mean \pm SD & $0.10 \pm 0.03$ & $0.34 \pm 0.11$ & & \\
\hline Median & 0.10 & 0.32 & & \\
\hline $\begin{array}{l}\text { \% of Change from } \\
\text { time of implant } \\
\text { placement to } 7 \\
\text { months } \\
\text { Min. - Max }\end{array}$ & $4.82-13.04$ & $13.90-38.20$ & \multirow[t]{3}{*}{0.0} & \multirow[t]{3}{*}{$<0.001$} \\
\hline Mean \pm SD & $7.16 \pm 2.44$ & $26.75 \pm 8.25$ & & \\
\hline Median & 6.10 & 30.17 & & \\
\hline Vertical bone loss & Study $(n=10)$ & \begin{tabular}{|c|} 
Control (n= \\
$10)$
\end{tabular} & $\mathbf{U}$ & $\mathbf{P}$ \\
\hline $\begin{array}{l}\text { Change from time of } \\
\text { implant placement to } \\
4 \text { months } \\
\text { Min. - Max }\end{array}$ & $0.06-0.40$ & $0.14-2.94$ & \multirow[t]{3}{*}{$3.0^{*}$} & \multirow[t]{3}{*}{$<0.001^{*}$} \\
\hline Mean \pm SD & $0.16 \pm 0.13$ & $0.86 \pm 0.76$ & & \\
\hline Median & 0.11 & 0.72 & & \\
\hline $\begin{array}{l}\text { Change from time of } \\
\text { implant placement to } \\
7 \text { months } \\
\text { Min. - Max } \\
\end{array}$ & $0.16-0.81$ & $0.89-3.64$ & \multirow[t]{3}{*}{0.0} & \multirow[t]{3}{*}{$<0.001^{*}$} \\
\hline Mean \pm SD & $0.44 \pm 0.24$ & $1.61 \pm 0.78$ & & \\
\hline Median & 0.34 & 1.45 & & \\
\hline $\begin{array}{l}\% \text { of Change from } \\
\text { time of implant } \\
\text { placement to } 7 \\
\text { months } \\
\text { Min. - Max } \\
\end{array}$ & $1.32-6.71$ & $6.52-30.38$ & \multirow[t]{3}{*}{$1.000^{*}$} & \multirow[t]{3}{*}{$<0.001^{*}$} \\
\hline Mean \pm SD & $3.33 \pm 1.81$ & $12.82 \pm 6.68$ & & \\
\hline \begin{tabular}{|l|} 
Median \\
\end{tabular} & 2.61 & \begin{tabular}{|l|}
10.85 \\
\end{tabular} & & \\
\hline
\end{tabular}

$\mathrm{U}, \mathrm{p}: \mathrm{U}$ and $\mathrm{p}$ values for Mann Whitney test for comparing between the two groups

*: Statistically significant at $\mathrm{p} \leq 0.05$

\section{CONCLUSIONS}

This study concluded that retaining a buccal shell of the root in conjunction with immediate implant placement is a viable technique to achieve osseointegration without any inflammatory response.

The socket shield technique appears to be a safe technique to preserve alveolar bone as horizontal and vertical bone loss was decreased when compared to conventional implantation. Also this technique is a minimally invasive implantological approach with high esthetic outcomes 


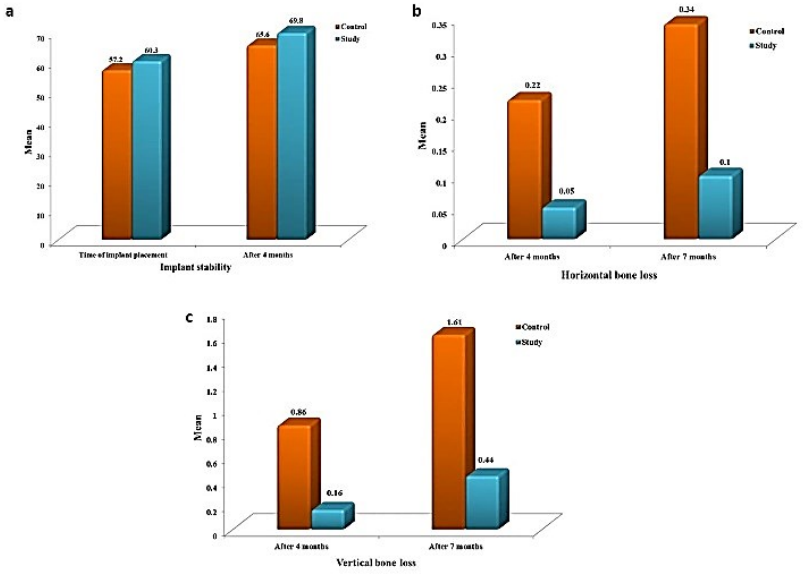

Figure (6): Charts showing (A) Comparison between the two studied groups according to implant stability quotient (ISQ). (B) Comparison between the two studied groups according horizontal bone loss. (C) Comparison between the two studied groups according to vertical bone loss.

\section{REFERENCES}

1. Limor AA, George AZ. Clinical effectiveness of implant supported single tooth replacement. The Toronto study. Int J Oral Maxillofac Implants. 1996; 11:311-21.

2. Henry P J. Tooth loss and implant replacement. Aust Dent J. 2000; 45:150-72.

3. Botticelli D, Persson LG, Lindhe J, Berglundh T. Bone tissue formation adjacent to implant placed in fresh extraction sockets: an experimental study in dogs. Clin Oral Implants. 2006; 17:351-8.

4. Fickl S, Zuhr O, Wachtel H, Bolz W, Huerzeler MB. Hard tissue alterations after socket preservation: an exprimental study in the beagle dog. Clin Oral Implants Res. 2008;19: 1111-8.

5. Carmagnola D, Adriaens P, Berglundh T. Healing of human extraction sockets filled with Bio-Oss. Clin Oral Implants Res. 2003; 14:137-43.

6. Nevins M, Camelo M, De Paoli S, Friedland B, Schenk RK, Parma-Benfenati S, et al. A study of the fate of the buccal wall of extraction sockets of teeth with prominent roots. Int J Periodontics Restorative Dent. 2006; 26:19-29.

7. Araújo M, Linder E, Wennström J, Lindhe J. The influence of Bio-Oss collagen on healing of an extraction socket: an experimental study in the dog. Int J Periodontics Restorative Dent. 2008; 28:123-35.

8. Araújo M, Linder E, Lindhe J. Effect of a xenograft on early bone formation in extraction sockets: an experimental study in dog. Clin Oral Implants Res. 2009;20:1-6.

9. Chen C L, Pan Y H. Socket shield technique for ridge preservation: A case report. J Prosthondontics Implantology. 2013; 2:16-21.

10. Lekovic V, Camargo PM, Klokkevold PR, Weinlaender M, Kenney EB, Dimitrijevic B, et al. Preservation of alveolar bone in extraction sockets using bioabsorbable mebranes. J Periodontol. 1998;69:1044-9.

11. Lekovic V, Kenney E, Weinlaender M, Han T, Klokkevold $\mathrm{P}$, Nedic M, et al. A bone regenerative approach to alveolar ridge maintenance following tooth extractions. Report of 10 cases. J Periodontol.1997;68:563-70.

12. Araújo MG, Lindhe J. Dimensional ridge alterations following tooth extraction: An experimental study in the dog. J Periodontol. 2005; 32:212-8.
13. Hürzeler MB, Zuhr O, Schupbach $P$, Rebele SF, Emmanouilidis N, Fickl S. The socket shield technique: a proof-of-principle report. J Clin Periodontal. 2010; 37: 855-62.

14. Filippi A, Pohl Y, von Arx T. Decoronation of an ankylosed tooth for preservation of alveolar bone prior to implant placement. Dent Traumatol 2001; 17:93-5.

15. Andersson L, Emami-Kristiansen Z, Högström J. Single tooth implant treatment of tooth loss after trauma: A retrospective clinical and interview study. Dent Traumatol 2003; 19:126-31.

16. Malmgren, B., Cvek, M., Lundberg, M. \& Frykholm, A. Surgical treatment of ankylosed and infrapositioned reimpla nted incisors in adolescents. Scand J Dent Res.1984; 92:391-9.

17. Malmgren, O., Malmgren, B. \& Goldson, L. Orthodontic Management of the Traumatized Dentition. 3rd ed. Munksgaard, Copenhagen;1994: pp. 587-633.

18. Salama M, Ishikawa T, Salama H, Funato A, Garber D. Advantages of the root submergence technique for pontic site development in esthetic implant therapy. Int $\mathrm{J}$ Periodontics Restor Dent. 2007; 27:521-7.

19. Mombelli A, Muhle T, Bragger U, Lang NP, Burgin WB. Comparison of periodontal and peri-implant probing by depth-force pattern analysis Clin Oral Implants Res. 1997; 8:448-54.

20. Muhlemann HR, Son S. Gingival sulcus bleeding--a leading symptom in initial gingivitis. Helv Odontol Acta. 1971; 15:107-13.

21. Irinakis T. Rational for socket preservation after extraction of single rooted tooth when planning for future implant placement. J Can Dent Assoc. 2006; 72:917-22.

22. Lang NP, Berglundh T, Heitz-Mayfield LJ, Pjetursson BE, Salvi GE, Sanz M. Consensus statements and recommended clinical procedures regarding implant survival and complications. Int J Oral Maxillofac Implants. 2004;19:150-4

23. Degidi M, Daprile G, Piattelli A. Determination of primary stability: A comparison of the surgeon's perception and objective measurements. Int J Oral Maxillofac Implants. 2010; 25:558-61.

24. Bäumer D, Zuhr O, Rebele S, Schneider D, Schupbach P, Hürzeler M. The socket-shield technique: first histological, clinical, and volumetrical observations after separation of the buccal tooth segment - a pilot study. Clin Implant Dent Relat Res. 2015; 17:71-82.

25. Bäumer D, Zuhr O, Rebele S, Hürzeler M. Socket Shield Technique for immediate implant placement - clinical, radiographic and volumetric data after 5 years. Clin Oral Implants Res. 2017;0:1-9.

26. Abadzhiev M, Nenkov P, Velcheva P. Conventional immediate implant placement and immediate placement with socket-shield technique -Which is better. Int J Clin Med. 2014; 1:176-80.

27. Lindhe J. Clinical periodontology and implant dentistry. J Clin Periodontol 2008; 35: 992-1000.

28. Baumer D, Zuhr O, Rebele S, Schneider D, Schupbach P, Hurzeler M. _e Socket-Shield Technique: First Histological, Clinical, and Volumetrical Observations after Separation of the Buccal Tooth Segment- A Pilot Study. Wiley Periodicals, Inc.2013;0:1-12

29. Malmgren B. Decoronation: how, why, and when? J Calif Dent Assoc. 2000;28:846-54. 
30. Malmgren B, Malmgren O. Rate of infraposition of reimplanted ankylosed incisors related to age and growth in children and adolescents. Dent Traumatol. 2002; 18:28-36.

31. Cohenca N, Stabholz A. Decoronation - a conservative method to treat ankylosed teeth for preservation of alveolar ridge prior to permanent prosthetic reconstruction: literature review and case presentation. Dent Traumatol. 2007; 23:8794.

32. Sapir S, Shapira J. Decoronation for the management of an ankylosed young permanent tooth. Dent Traumatol. 2008;24131-5.

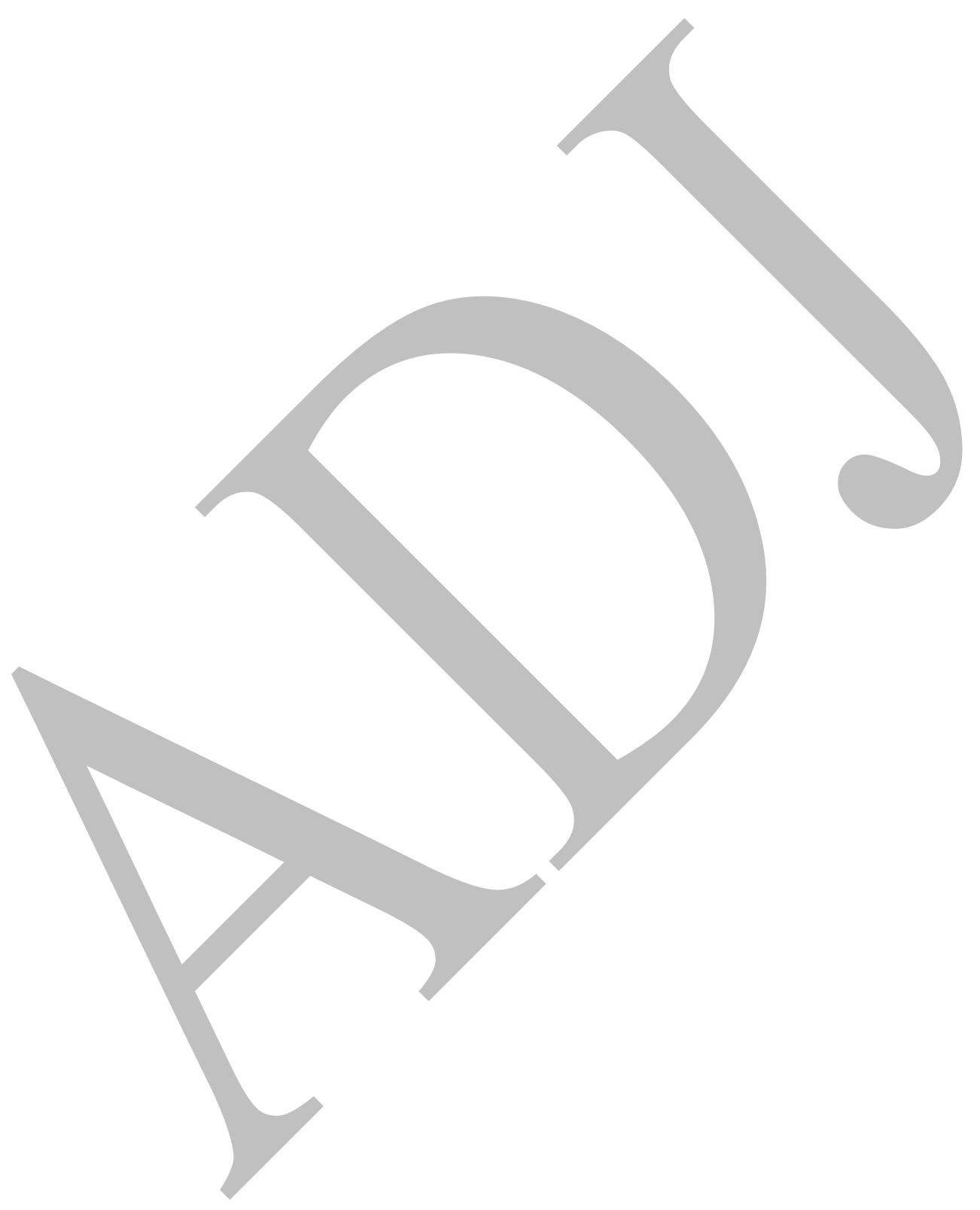

